\title{
Recent and future threats to the Endangered Cuban toad Peltophryne longinasus: potential additive impacts of climate change and habitat loss
}

\author{
Marlon E. Cobos and Roberto Alonso Bosch
}

\begin{abstract}
Habitat loss and climate change are major threats to amphibian species worldwide. We combined niche modelling under various climatic scenarios with analysis of habitat loss and the appropriateness of Cuban protected areas to identify major risk zones for the Endangered Cuban toad Peltophryne longinasus. Four subspecies with disjunct distributions associated with mountain forests are recognized. Our results suggest that the western subspecies, $P$. longinasus longinasus and $P$. longinasus cajalbanensis, are at risk from global warming, habitat degradation and potential additive effects. Peltophryne longinasus dunni, in central Cuba, has the lowest threat level related to climate change and habitat loss but could become increasingly threatened by the presence of the infectious disease chytridiomycosis. The eastern subspecies, $P$. longinasus ramsdeni, faces moderate impacts of climate change and habitat loss; however, low opportunity of migration to new areas and population decline justify a high threatened status for this subspecies. Our results predict minor temperature increases and precipitation decreases in the future. Nevertheless, at the biological level these changes could generate variations in species physiology, vocal behaviour and prey availability, and could probably increase the risk of predation. In Cuba protected areas have contributed to avoiding excessive forest loss but the potential impact of climate change was not considered in their original design. Our findings confirm that all subspecies of $P$. longinasus are threatened but management measures should be tailored according to the various predicted impacts.
\end{abstract}

Keywords Amphibian decline, Bufonidae, climate change, forest cover loss, habitat suitability models, Peltophryne, protected areas

To view supplementary material for this article, please visit https://doi.org/10.1017/So030605316000612

Marlon E. Cobos Departamento de Biología Animal y Humana, Facultad de Biología, Universidad de La Habana, Havana, Cuba

Roberto Alonso Bosch (Corresponding author) Museo de Historia Natural Felipe Poey, Facultad de Biología, Universidad de La Habana, street 25 \#455. Vedado, Plaza de la Revolución, Havana, 10400, Cuba

E-mail ralonso@fbio.uh.cu

Received 18 January 2016. Revision requested 17 March 2016.

Accepted 22 June 2016. First published online 28 October 2016.

\section{Introduction}

The causes of global amphibian decline are diverse but 1 the majority are anthropogenic (Carey \& Alexander, 2003; Beebee \& Griffiths, 2005, Brum et al., 2013). Given the complexity of ecological processes the causes of species decline are typically studied and managed in isolation but multiple threats, such as climate change and habitat loss (Mantyka-Pringle et al., 2012), can affect species and ecosystems concurrently (Rohr et al., 2008). Furthermore, changes in climate could modify dispersion and infection characteristics of the chytrid fungus, Batrachochytrium dendrobatidis (Pounds et al., 2006; Rödder et al., 2010). Although a global estimate of areas at risk from the occurrence of these threats has been developed (Hof et al., 2011), variation in local conditions and species necessitates greater precision in identifying priority areas for conservation and management (Mantyka-Pringle et al., 2014).

Peltophryne longinasus is a bufonid endemic to Cuba and is a uniquely polytypic species of the genus in the Caribbean basin (Henderson \& Powell, 2009). There are four recognized subspecies, with disjunct distributions in mountainous areas (Díaz \& Cádiz, 2008). Peltophryne longinasus longinasus and $P$. longinasus cajalbanensis inhabit the Alturas de Pizarras in the south of Pinar del Río province and Cajálbana upland, respectively. Peltophryne longinasus dunni is distributed in the Guamuhaya mountain range in the centre of the island and is threatened by the chytrid fungus (Díaz et al., 2007). Although only one sick and dying individual has been found, in October 2006, the presence of the disease in this population was confirmed. Since that date no more cases have been reported. Peltophryne longinasus ramsdeni is known only from the Guaso upland in Guantanamo province, in eastern Cuba, but it has not been found since 1976 (Valdes de la Osa \& Ruiz García, 1980).

This diurnal species occupies a variety of vegetation types, mainly woodlands (pinewoods and mesic broadleaf forests) and secondary vegetation, at altitudes of $100-820 \mathrm{~m}$ (Valdes de la Osa \& Ruiz García, 1980; Díaz \& Cádiz, 2008), and reproduces in mountain streams (Valdés de la Osa \& Ruiz García, 1980). Peltophryne longinasus is categorized as Endangered on the IUCN Red List because its Area of Occupancy is $<500 \mathrm{~km}^{2}$, its distribution is severely fragmented and the extent of its upland forest habitat is declining (Hedges \& Díaz, 2004). Its threat status, ecological and morphological features and disjunct distribution make it an 
ideal species to evaluate the additive threats of climate change and habitat loss.

Habitat fragmentation and climate change have been recognized as two principal threats to biodiversity in Cuba (CITMA, 2014) but their possible additive impacts on amphibian diversity have received little consideration. Here we (1) evaluate the potential impact of predicted climate change scenarios for 2050 and 2070 on habitats suitable for $P$. longinasus, (2) estimate habitat loss (measured as forest lost) during 2000-2012 in the areas suitable for this species, (3) identify suitable areas for P. longinasus affected by additive stressors (habitat loss, disease and climate change), and (4) assess the representation of suitable areas for the species (for 2000, 2050 and 2070 scenarios) and the threats it faces within Cuban protected areas.

\section{Study area}

The study area (the Cuban archipelago) was divided into four physical-geographical regions (Fig. 1), simplifying the regionalization of Mateo \& Acevedo (1989). Regions inhabited by $P$. longinasus (western, central and eastern Cuba) comprise the more densely forested areas of the archipelago (Mateo \& Acevedo, 1989).

\section{Methods}

We used ecological niche models to identify areas suitable for $P$. longinasus and predict future changes in these areas. We evaluated recent forest loss using the results of Hansen et al. (2013), to identify patterns and levels of habitat degradation. We also assessed climate change in areas where suitable conditions will decline in the future, using the bioclimatic variables of the WorldClim database (Hijmans et al., 2005). With the resultant information we identified suitable areas potentially affected by additive threats from climate change, habitat loss and chytridiomycosis. We also evaluated the representation of the suitable areas and threats in protected areas.

\section{Climatic data}

The modelling dataset included 13 bioclimatic variables (Table 2) obtained from the WorldClim database version 1.4 ( $\mathrm{S}_{4}$ data group) at a resolution of 30 arc-seconds (Hijmans et al., 2005). We selected these variables on the assumption that they are most strongly related to the natural history of the studied species. We did not check for collinearity among our selected variables. We followed the criteria of Braunisch et al. (2013), who stated that the inclusion of several correlated, potentially relevant variables in the same model may be preferable when the intention is to predict rather than infer, as it may lead to a 'less wrong' result than when operating with only a single, irrelevant predictor arbitrarily.

To evaluate the effect of climate change by 2050 and 2070 on the potential distribution of $P$. longinasus we used two Representative Concentration Pathway (RCP) scenarios (2.6 and 8.5) of the general circulation model of the Beijing Climate Center. These scenarios describe two climatic configurations based on different concentrations of greenhouse gases (Moss et al., 2008). The RCP 2.6 scenario assumes that concentrations of greenhouse gases will increase in the future, reaching a maximum by 2040 , and the RCP 8.5 assumes that concentrations will continue to increase even up to 2100 (IPCC, 2013). Future bioclimatic variables were obtained from the WorldClim database.

\section{Habitat suitability models and projections}

We used distribution records (Alonso, 2011) and the aforementioned bioclimatic variables as presence and environmental data. To prevent possible errors duplicate records were removed. With the remaining 20 samples and selected variables we created habitat suitability models in MaxEnt 3.3.3k (Phillips et al., 2006), using its default configuration and 50 replicates for bootstrapping. To obtain presence-absence data from the mean logistic model we used the 1oth percentile threshold (Peterson et al., 2007), which should not be sensitive to extreme environmental values (Radosavljevic \& Anderson, 2014). We consider it to be appropriate because a small sample size could increase the weight of extreme records in the model (Araujo \& Peterson, 2012) and consequently the estimated area of suitable habitat for the species. To evaluate model performance we used the area under the receiver operating characteristic curve (AUC; Phillips et al., 2006), difference of AUC $\left(\right.$ AUC $_{\text {DIFF }}$; Warren \& Seifert, 2011) and $10 \%$ training omission rate (Peterson et al., 2011).

Habitat suitability models created for the year 2000 were projected to 2050 and 2070 using MaxEnt. Results of each projection were compared with the initial model, considering the change in suitable areas (presence areas). For the future projections we identified areas where suitable climatic conditions for P. longinasus could be lost, suitable areas consistent with compared scenarios, and potentially new suitable areas. The conserved range is the area of overlap between each of the projected ranges and the 2000 range.

Where a loss of suitable habitat was predicted we used QGIS 2.8 (QGIS Development Team, 2015) to calculate differences in variables between 2000 and projected values for 2050 and 2070 (using all pixel values) for the two scenarios (RCP 2.6 and 8.5).

We used data from the Global Forest Change database (Hansen et al., 2013) to evaluate loss of forest cover, which we considered to be an indicator of fragmentation and 


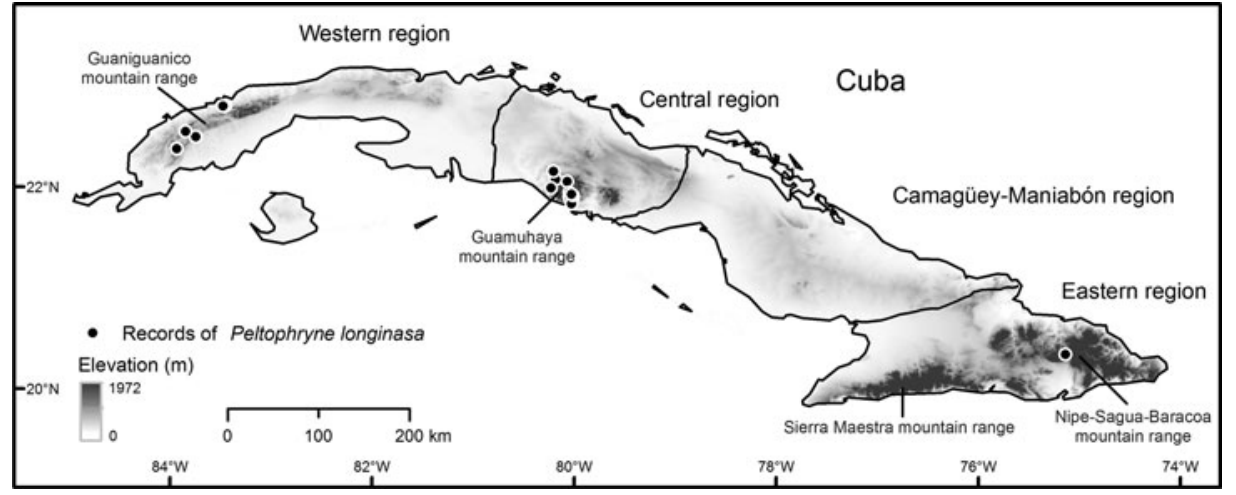

FIG. 1 Distribution of records of Peltophryne longinasus in Cuba, which is divided into physicalgeographical regions, based on Mateo \& Acevedo (1989). habitat loss. We estimated annual forest loss (resolution 30 $\mathrm{m}$ ) in the quadrants that include the Cuban archipelago, and extracted the areas of interest in the layer composition of forest cover loss (2000-2012), using the suitable areas identified by habitat suitability modelling. In QGIS we calculated the surface area of deteriorated areas by year for each region and for all areas of suitable habitat, attempting to discriminate between vegetation types according to the vegetation map of Estrada et al. (2011).

To detect areas affected by additive stressors we created a map of known distribution records of $P$. longinasus subspecies, projected climate change, trends in temperature and precipitation, habitat loss (density of forest cover loss), and reported presence of Batrachochytrium dendrobatidis. Potential impacts of climate change were categorized as High, Medium or Low (based on projected habitat loss), and were compared among regions. We also identified areas predicted to become more suitable for $P$. longinasus as a result of climate change.

We assessed the importance of protected areas for conservation of $P$. longinasus and its habitats using the map of Cuba's national system of protected areas (CNAP, 2013). We calculated the area of current and future suitable habitat for the species within protected areas. We also estimated the area of suitable habitat that will potentially be lost under future climate scenarios. Finally, we compared the areas of forest loss in suitable habitat areas inside and outside protected areas in each region of the study area.

\section{Results}

Habitat suitability models Habitat suitability models yielded high mean values of AUC (0.98 \pm SD 0.03$)$, low $\mathrm{AUC}_{\mathrm{DIFF}}(0.02 \pm \mathrm{SD} 0.05)$ and a mean $10 \%$ training omission rate of $0.053 \pm \mathrm{SD} 0.02$. The AUC results indicate good predictive power, and $\mathrm{AUC}_{\mathrm{DIFF}}$ and the $10 \%$ training omission rate indicate that overfitting could be avoided in these models. The major contributing bioclimatic variables were annual mean temperature (BIO1), maximum temperature of warmest month (BIO5), and temperature seasonality (BIO4). The logistic output for 2000 revealed a high probability of presence of $P$. longinasus in mountain zones in all three regions inhabited by the species. In the initial binary results (Fig. 2a,b) derived from reclassification of the mean logistic model (probability of presence $>0.24=$ mean 1oth percentile threshold) we observed a fragmented pattern with suitable areas in all regions except Camagüey-Maniabón.

Potential modifications of suitable areas Suitable areas for P. longinasus (Fig. 2a,b) in 2000 represented $2.98 \%$ of all Cuban territory, with substantial decreases predicted by future projections (Fig. 2c,d). By 2050 losses of $51.03 \%$ (RCP 2.6) and 62.64\% (RCP 8.5) of suitable habitat are expected, and the western region will be most affected, with reductions of 84.5 and $93.46 \%$ in the respective scenarios (Table 1). Projections for 2070 are similar, with decreases of $48.98 \%$ (RCP 2.6) and $78.23 \%$ (RCP 8.5). However, in the Sierra Maestra mountain range (eastern region) the area of suitable habitat is predicted to increase significantly in scenario RCP 8.5 (Fig. 2c,d), but $P$. longinasus has never been found there. In scenario RCP 2.6, even though suitable habitat is predicted to diminish by 2050 , an improvement relative to 2050 is expected by 2070 , especially in the central and western regions. The conserved range (suitable areas consistent with compared scenarios) will be proportionally higher in the central and eastern regions in comparison with the western region (Table 1). Suitable areas are expected to be found at higher altitudes in the future (relative to 2000). By 2050 mean altitudinal increases of $197.22 \mathrm{~m}$ (RCP 2.6) and $279.38 \mathrm{~m}$ (RCP 8.5) are projected. By 2070 the altitude of suitable habitat could increase by $148 \mathrm{~m}$ (RCP 2.6) and $349.50 \mathrm{~m}$ (RCP 8.5) relative to 2000 .

Expected climate change in areas predicted to become unsuitable for $\mathrm{P}$. longinasus In areas where suitable 
TABLE 1 The potential distribution range of the Cuban toad Peltophryne longinasus in western, central and eastern Cuba in 20oo, and projected values for 2050 and 2070 under two climate change scenarios (RCP 2.6 and RCP 8.5). The conserved range is the area of overlap between each of the projected ranges with the 2000 range.

\begin{tabular}{|c|c|c|c|c|c|c|c|c|c|}
\hline \multirow[b]{2}{*}{ Scenario* } & \multirow[b]{2}{*}{ Year } & \multicolumn{2}{|l|}{ Western } & \multicolumn{2}{|l|}{ Central } & \multicolumn{2}{|l|}{ Eastern } & \multicolumn{2}{|l|}{ Total } \\
\hline & & $\begin{array}{l}\text { Potential } \\
\text { distribution } \\
\text { range }\left(\mathrm{km}^{2}\right)\end{array}$ & $\begin{array}{l}\text { Conserved } \\
\text { range } \\
\left(\mathrm{km}^{2}\right)\end{array}$ & $\begin{array}{l}\text { Potential } \\
\text { distribution } \\
\text { range }\left(\mathrm{km}^{2}\right)\end{array}$ & $\begin{array}{l}\text { Conserved } \\
\text { range } \\
\left(\mathrm{km}^{2}\right)\end{array}$ & $\begin{array}{l}\text { Potential } \\
\text { distribution } \\
\text { range }\left(\mathrm{km}^{2}\right)\end{array}$ & $\begin{array}{l}\text { Conserved } \\
\text { range } \\
\left(\mathrm{km}^{2}\right)\end{array}$ & $\begin{array}{l}\text { Potential } \\
\text { distribution } \\
\text { range }\left(\mathrm{km}^{2}\right)\end{array}$ & $\begin{array}{l}\text { Conserved } \\
\text { range } \\
\left(\mathrm{km}^{2}\right)\end{array}$ \\
\hline & 2000 & $1,012.02$ & & $1,015.89$ & & $1,270.27$ & & $3,298.18$ & \\
\hline \multirow[t]{2}{*}{ RCP 2.6} & 2050 & 156.97 & 156.71 & 578.13 & 577.84 & $1,053.33$ & 880.46 & $1,788.43$ & $1,615.01$ \\
\hline & 2070 & 257.84 & 257.22 & 611.20 & 610.96 & 951.55 & 814.54 & $1,820.59$ & $1,682.72$ \\
\hline \multirow[t]{2}{*}{ RCP 8.5} & 2050 & 66.24 & 66.24 & 459.27 & 459.27 & 964.43 & 706.43 & $1,489.93$ & $1,231.93$ \\
\hline & 2070 & 0.00 & 0.00 & 336.35 & 336.35 & 595.63 & 381.54 & 931.98 & 717.89 \\
\hline
\end{tabular}

${ }^{*} \mathrm{RCP} 2.6$ assumes that concentrations of greenhouse gases will increase in the future, reaching a maximum by 2040 , and RCP 8.5 assumes that concentrations will continue to increase even up to 2100 .

conditions for the species will be lost, values of all temperature variables (except mean diurnal range, $\left.\mathrm{BIO}_{2}\right)$ are expected to increase in both climate scenarios (Table 2). Significant increases of temperature and decreases of three of six precipitation variables by 2070 are predicted (RCP 8.5). Precipitation in the driest month and driest quarter (BIO14 and BIO 17) is predicted to decrease significantly by 2070 (RCP 2.6). Similarly, a reduction in precipitation seasonality (coefficient of variation) by 2050 is expected (RCP 2.6). We also recorded increments in precipitation in the wettest month (BIO13) and precipitation seasonality (BIO15) by 2050 (RCP 8.5) and 2070 (RCP 2.6) (Table 2).

Habitat loss in areas that were suitable in 2000 Total initial forest cover (2000) in areas suitable for P. longinasus comprised $3,043.75 \mathrm{~km}^{2}$, with the majority of the vegetation distributed in the eastern region (Fig. 3). The most significant forest loss during 2000-2012 took place in the western region (Figs $3 \& 4$ ), where major losses were recorded in 2008. Significant reductions in forest cover occurred in the central and eastern regions in 2005 and 2002, respectively (Fig. 3b). Peltophryne longinasus has been recorded in at least eight distinct vegetation formations (Supplementary Table S1). These formations occupy $37.27 \%$ of the species' total suitable area. We identified that secondary vegetation, Pinus caribaea and $P$. tropicalis pinewoods, were most affected in the western region, submontane mesophyllous evergreen forests and secondary vegetation in the central, and submontane mesophyllous evergreen forests in the eastern region.

Areas affected by additive stressors Predicted future trends include an increase in temperature and a decrease in precipitation throughout the entire area of suitable habitat for $P$. longinasus. Three types of additive threats have also been identified: climate change and habitat loss, climate change and chytridiomycosis, and habitat loss and chytridiomycosis. The first combination was detected throughout the species' range (Fig. 5) but the level of impact varied among regions, and therefore the subspecies will be affected differentially. The greatest impacts of climate change with habitat loss were observed in the western region, intermediate impacts were detected in the eastern region, and the lowest impact was observed in the central region. The second and third types of additive threats appear to occur only in the central region, as a result of the reported presence of chytridiomycosis in this zone and the absence of connectivity with other regions.

Importance of protected areas The current percentage of suitable habitat area for P. longinasus (Fig. 2b) within protected areas is $36.6 \%$ but this is expected to decrease under all future scenarios (Supplementary Table S2). The eastern region had the highest initial and future representations of suitable habitat within protected areas in all evaluated scenarios. We predict that by 2050 (RCP 2.6) suitable areas within protected areas will be reduced by $30.15 \%$, and by $207024.99 \%$. In the RCP 8.5 scenario we predict reductions of 29.26 and $56.23 \%$ by 2050 and 2070, respectively. Nevertheless, the majority of the reduction in suitable areas in the future (Fig. $2 \mathrm{c}, \mathrm{d}$ ) will occur outside protected areas, with only $26.34-32.77 \%$ of losses occurring within protected areas (Supplementary Table $\left.S_{3}\right)$. We detected considerable differences in forest loss during 2000-2012 inside and outside protected areas (Supplementary Table $\mathrm{S}_{4}$ ), with only $8.6 \%$ of the forest loss occurring inside protected areas.

\section{Discussion}

Our results indicate that, in the future, areas of habitat suitable for $P$. longinasus will be reduced. Similar studies have reported spatial changes in suitable areas (decrease and 
TABLE 2 Mean values (min., max.) of bioclimatic variables for the initial (2000) distribution range of P. longinasus, and differences between projected values for 2050 and 2070 under two climate scenarios (RCP 2.6 and RCP 8.5) and 2000 values.

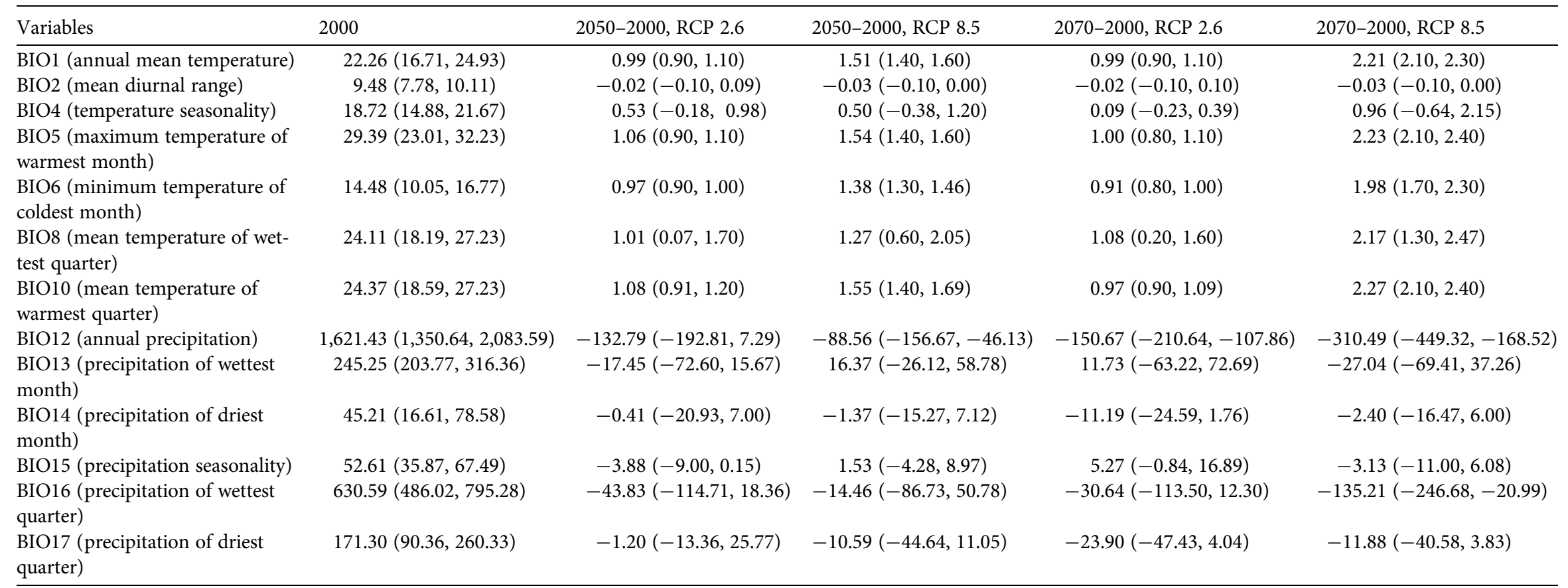




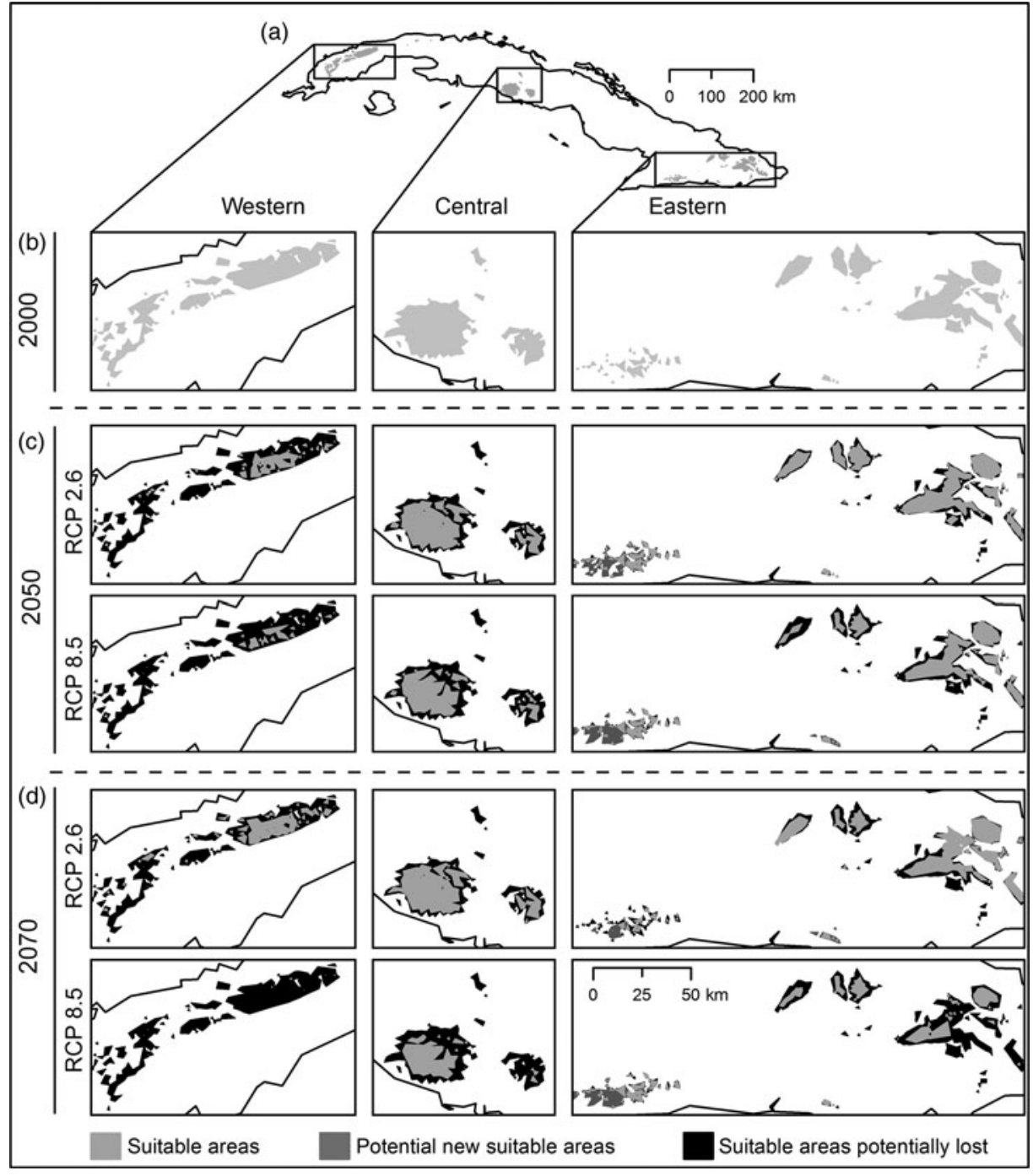

FIG. 2 Result of habitat suitability models for Peltophryne longinasus: Potential distribution range of Peltophryne longinasus for 2000 (a \& b). Predicted change in species potential distribution ranges by (c) 2050 and (d) 2070. displacement of ranges) for many herpetofaunal species in Europe and South America (Araújo et al., 2006; Zank et al., 2014; Courtois et al., 2016). Suitable areas for P. longinasus will be found at high altitudes; this concurs with the general evidence of changes in species' distributions in response to global warming (Walther et al., 2002; Raxworthy et al., 2008). However, the archipelagic nature of Cuba, the lack of connectivity among ranges and the presence of barriers will impede future movement of the subspecies of $P$. longinasus to places with suitable conditions at other latitudes (i.e. the Sierra Maestra mountain range). Displacement to adjacent locations at higher altitudes within the same region is therefore the most likely alternative.

Not all subspecies have the same opportunity and ability to move to higher altitudes in the same region. Our results suggest that $P$. longinasus dunni has more opportunities for displacement because suitable areas adjacent to its current range will be less affected compared to other subspecies in other regions. Further studies on movement patterns are needed to investigate the capability of each subspecies to move to higher altitudes, and to obtain a better understanding of the impact of climate change on this species sensu lato.

Projected decreases in precipitation could also affect the typical reproductive phenology of $P$. longinasus. Such decreases could reduce the spatial and temporal accessibility of sites for calling and breeding, and also affect nesting success and optimum larval development. In the microhabitat of $P$. longinasus longinasus air temperature is $26-31^{\circ} \mathrm{C}$ (Díaz \& Cádiz, 2006) and forecasted changes in bioclimatic variables include temperature changes. At the biological level these could generate variations in physiology, vocal behaviour and the availability and accessibility of prey, and could potentially increase the risk of predation (Blaustein et al., 2011; Li et al., 2013).

Amphibian species with small ranges tend to have more habitat specificity, which makes them vulnerable to habitat alterations (Williams \& Hero, 1998). The deterioration in 

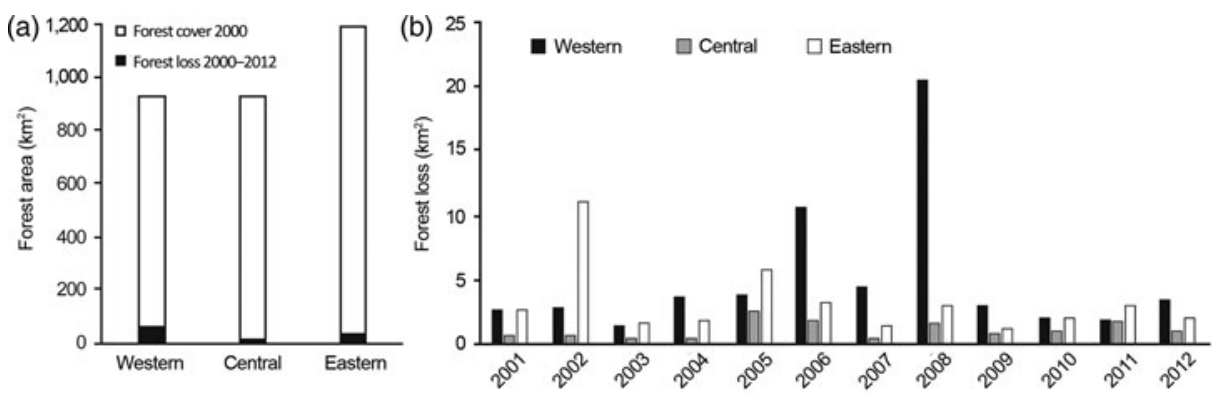

Fig. 3 (a) Forest cover in the potential distribution range of Peltophryne longinasus in 2000 , and total forest loss during 20002012, in the western, central and eastern regions of Cuba (Fig. 1).

(b) Forest loss per year during 2001-2012 in each region.
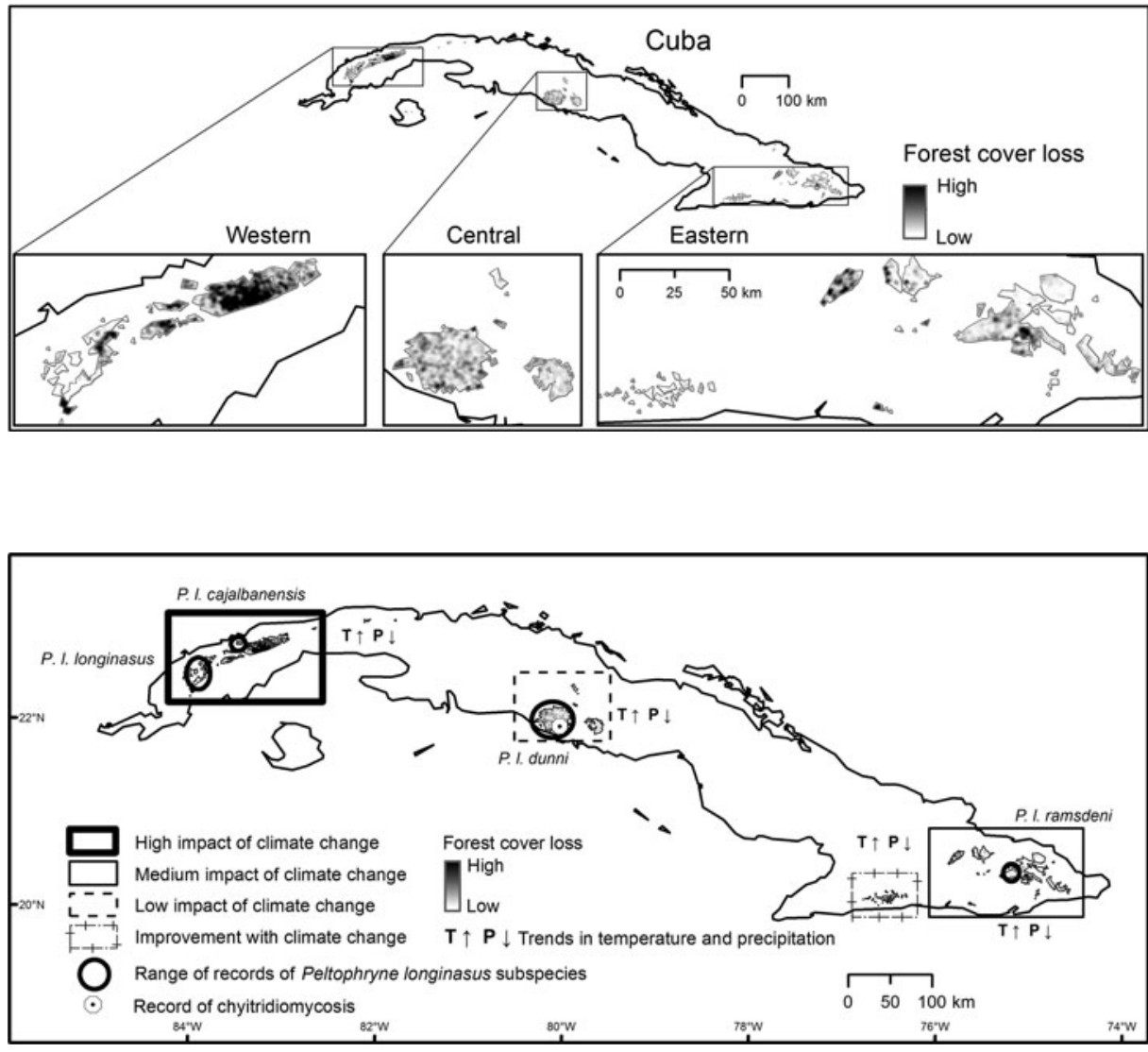

FIG. 4 Density of forest cover loss during 2000-2012 in areas of initially suitable habitat for Peltophryne longinasus in the western, central and eastern regions of Cuba.
FIG. 5 Additive stressors of climate change and habitat loss on the distribution range of Peltophryne longinasus in Cuba. forest cover is resulting in loss and fragmentation of habitats of $P$. longinasus in some of its most frequented vegetation types (e.g. Pinus forests). Although we have taken into account a period of only 12 years prior to our future projections, there was no apparent decrease in deforestation within this period, and deforestation is likely to continue, especially outside protected areas. In fragmented landscapes dispersion is often insufficient to maintain population viability (Cushman, 2006), and processes such as habitat split are common in fragmented landscapes with complex topography (Becker et al., 2010). Forest cover loss is therefore a significant concern, as it has been shown that habitat split, loss and fragmentation affect principally species with aquatic larvae (Fonseca et al., 2008).
Other studies have suggested potential synergistic effects of climate change and other stressors when they co-occur (Pyke, 2004; Brook et al., 2008; Mantyka-Pringle et al., 2012). We have identified areas where additive effects of global warming and habitat loss could be occurring, alerting us to potential synergies between these threats (Fig. 5).

Peltophryne longinasus longinasus and P. longinasus cajalbanensis will face major risks from the additive effects of global warming and habitat degradation. Peltophryne longinasus dunni (which may represent a distinctive form and is probably a ninth species of Cuban Peltophryne; Alonso et al., 2012) is the subspecies with the lowest level of risk linked to these threats; however, it may also be threatened by the presence of the chytrid fungus. This pathogen disperses rapidly 
(Lips et al., 2008) and its spread may be facilitated by anthropogenic activities (Weldon et al., 2004; Fisher \& Garner, 2007). Establishment and intensity of infection are highest in elevated places with lower temperatures and higher precipitation (Drew et al., 2006). Nevertheless, there is evidence that warmer years favour the development of the fungus at high elevations (Pounds et al., 2006; Harvell et al., 2009). Peltophryne longinasus ramsdeni will suffer intermediate effects in comparison with the other three subspecies. The almost non-existent possibility of migration to new, potentially suitable areas and the absence of records of this subspecies since 1976 justify its highly threatened status. However, it cannot yet be categorized as Extinct, given the few observations in the field and the lack of information on its biology, population size and habitat use. Based on our precautionary criteria we therefore categorize this subspecies as Critically Endangered, Possibly Extinct (CR A2ac; IUCN, 2015), until further surveys confirm, or not, that no individuals remain.

Our results show that all subspecies of $P$. longinasus are threatened; however, each one requires different research and management priorities according to the identified impacts. Habitat protection and restoration efforts could be a priority, especially in western areas where the major risks are potentially the additive effects of climate change and habitat loss. Further efforts are required to clarify the existence, prevalence, dissemination and pathogenicity of the chytrid fungus in relation to other natural and anthropogenic stressors in the central region. Some ex situ conservation initiatives began 10 years ago with a preliminary captive breeding protocol for $P$. longinasus longinasus (Díaz \& Cádiz, 2006). However, the differences in ecology and behaviour of subspecies (Valdés de la Osa \& Ruiz García, 1980) necessitate the development of variants of this protocol.

Amphibians are the group with the most species whose ranges fall completely outside protected areas (Nori et al., 2015). Although the original design of Cuba's national system of protected areas does not provide adequate protection for amphibians (Fong et al., 2015) and fails in the representation of suitable areas for P. longinasus (Supplementary Table $S_{3}$ ), it appears to have contributed to avoiding excessive forest loss (Supplementary Table $\mathrm{S}_{4}$ ).

Integration of multiple approaches and perspectives is needed to obtain more accurate information about how species and habitats may respond to climate change (Dawson et al., 2011). The synergies between ecological/ life history traits and environmental conditions demonstrate how a management strategy focused on multiple, diverse threats is a necessary precursor to any successful conservation action (Sodhi et al., 2008). This, together with adequate monitoring (e.g. Courtois et al., 2016), constitutes a basis for appropriate management decisions to conserve $P$. longinasus.

\section{Acknowledgements}

Many people helped $\mathrm{RAB}$ during the field expeditions to locate and verify the presence of the Cuban toad: Ariel Rodríguez, L. Yusnaviel García, Arturo Hernández, Luis Alvarez Lajonchere, and Rafael García-Morera. RAB thanks the National Center of Cuban Protected Areas and the Center for Inspection and Environmental Control for support and permission to access the study areas. Rafael Marquez and Chrystal S. Mantyka-Pringle provided comments on the text. Boris Fabres and Sergio J. Pastrana helped to improve the English. Prof. Tim Halliday offered valuable suggestions and corrections to the language, and helped enhance the quality of the article. Two anonymous reviewers provided constructive criticism. MEC is grateful for the support received during his postgraduate studies from the Secretaria Nacional de Educación Superior, Ciencia y Tecnología and the Instituto de Fomento del Talento Humano.

\section{Author contributions}

MEC and RAB conceived the study and wrote the article. $\mathrm{RAB}$ conducted all fieldwork and compiled the original database of geographical localities. MEC analysed the data and performed the modelling.

\section{References}

Alonso, R. (2011) Origen y diversificación del género Peltophryne (Amphibia: Anura: Bufonidae) en Cuba. PhD thesis. University of Havana, Havana, Cuba.

Alonso, R., Crawford, A.J. \& Bermingham, E. (2012) Molecular phylogeny of an endemic radiation of Cuban toads (Bufonidae: Peltophryne) based on mitochondrial and nuclear genes. Journal of Biogeography, 39, 434-451.

Araújo, M.B. \& Peterson, A.T. (2012) Uses and misuses of bioclimatic envelope modeling. Ecology, 93, 1527-1539.

Araújo, M.B., Thuiller, W. \& Pearson, R.G. (2006) Climate warming and the decline of amphibians and reptiles in Europe. Journal of Biogeography, 33, 1712-1728.

Becker, C.G., Fonseca, C.R., Haddad, C.F.B. \& Prado, P.I. (2010) Habitat split as a cause of local population declines of amphibians with aquatic larvae. Conservation Biology, 24, 287-294.

Beebee, T.J.C. \& Griffiths, R.A. (2005) The amphibian decline crisis: a watershed for conservation biology? Biological Conservation, 125, 271-285.

Blaustein, A.R., Han, B.A., Relyea, R.A., Johnson, P.T., Buck, J.C., Gervasi, S.S. \& Kats, L.B. (2011) The complexity of amphibian population declines: understanding the role of cofactors in driving amphibian losses. Annals of the New York Academy of Sciences, 1223, 108-119.

Braunisch, V., Coppes, J., Arlettaz, R., Suchant, R., Schmid, H. \& BolLmanN, K. (2013) Selecting from correlated climate variables: a major source of uncertainty for predicting species distributions under climate change. Ecography, 36, 971-983. 
Brook, B.W., Sodhi, N.S. \& Bradshaw, C.J.A. (2008) Synergies among extinction drivers under global change. Trends in Ecology of Evolution, 23, 453-460.

Brum, F.T., Gonçalves, L.O., Cappelatti, L., Carlucci, M.B. Debastiani, V.J., Salengue, E.V. et al. (2013) Land use explains the distribution of threatened New World amphibians better than climate. PLoS ONE, 8(4), e60742.

Carey, C. \& Alexander, M.A. (2003) Climate change and amphibian declines: is there a link? Diversity and Distributions, 9, 111-121.

Citma (Ministerio de Ciencia, Tecnología y Medio Ambiente) (2014) V Informe nacional al Convenio sobre la Diversidad Biológica. República de Cuba, La Habana, Cuba.

CNap (Centro Nacional de Áreas Protegidas) (2013) Plan del Sistema Nacional de Áreas Protegidas 2014-2020. Ministerio de Ciencias Tecnología y Medio Ambiente, La Habana, Cuba.

Courtois, E.A., Michel, E., Martinez, Q., Pineau, K., Dewynter, M., Ficetola, G.F. \& Fouquet, A. (2016) Taking the lead on climate change: modelling and monitoring the fate of an Amazonian frog. Oryx, 50, 450-459.

Cushman, S.A. (2006) Effects of habitat loss and fragmentation on amphibians: a review and prospectus. Biological Conservation, 128, 231-240.

Dawson, T.P., Jackson, S. T., House, J.I., Prentice, I.C. \& Mace, G.M. (2011) Beyond predictions: biodiversity conservation in a changing climate. Science, 332, 53-58.

Díaz, L.M. \& CÁdiz, A. (2006) Pflege und Vermehrung von Bufo longinasus Stejneger, 1905: Ein Beitrag zur Erhaltung dieser Art. Aquaristik Fachmagazin \& Aquarium heute, 38, 18-21.

Díaz, L.M. \& CÁdiz, A. (2008) Guía taxonómica de los anfibios de Cuba. Abc Taxa, 4, 1-294.

Díaz, L.M., CÁdiz, A., Chong, A. \& Silva, A. (2007) First report of chytridiomycosis in a dying toad (Anura: Bufonidae) from Cuba: a new conservation challenge for the island. EcoHealth, 4, 172-175.

Drew, A., Allen, E.J. \& Allen, L.J.S. (2006) Analysis of climatic and geographic factors affecting the presence of chytridiomycosis in Australia. Diseases of Aquatic Organisms, 68, 245-250.

Estrada, R., Martín, G., Martínez, P., Vioel, S., Capote, R., Reyes, I. et al. (2011) Mapa (BD-SIG) de vegetación natural y seminatural de Cuba v.1 sobre Landsat etm 7 slc-off gap filled, circa 2011. Memorias del IV Congreso de Manejo de Ecosistemas y Biodiversidad. La Habana, Cuba.

Fisher, M.C. \& GARner, T.W.J. (2007) The relationship between the emergence of Batrachochytrium dendrobatidis, the international trade in amphibians and introduced amphibian species. Fungal Biology Reviews, 21, 2-9.

Fong, A., Dávila, N.V. \& López-Iborra, G.M. (2015) Amphibian hotspots and conservation priorities in eastern Cuba identified by species distribution modeling. Biotropica, 47, 119-127.

Fonseca, C.R., Becker, C.G., Haddad, C.F.B. \& Prado, P.I. (20o8) Response to comment on "Habitat split and the global decline of amphibians". Science, 320, 874.

Hansen, M.C., Potapov, P.V., Moore, R., Hancher, M., Turubanova, S.A., Tyukavina, A. et al. (2013) High-resolution global maps of 21st-century forest cover change. Science, 342, 850-853.

Harvell, D., Altizer, S., Cattadori, I.M., Harrington, L. \& WEIL, E. (2009) Climate change and wildlife diseases: when does the host matter the most? Ecology, 90, 912-920.

Hedges, S.B. \& Díaz, L. (2004) Peltophryne longinasus. The IUCN Red List of Threatened Species 2004: e.T54693A11176718. Http://dx.doi. org/10.2305/IUCN.UK.2004.RLTS.T54693A11176718.en [accessed 11 August 2016].

Henderson, R.W. \& Powell, R. (2009) Natural History of West Indian Reptiles and Amphibians. University Press of Florida, Gainesville, Florida.
Hijmans, R.J., Cameron, S.E., Parra, J.L., Jones, P.G. \& Jarvis, A. (2005) Very high resolution interpolated climate surfaces for global land areas. International Journal of Climatology, 25, 1965-1978.

Hof, C., Araújo, M.B., Jetz, W. \& Rahbek, C. (2011) Additive threats from pathogens, climate and land-use change for global amphibian diversity. Nature, 480, 516-519.

IPCC (Intergovernmental Panel on Climate Change) (2013) Summary for policymakers. In Climate Change 2013: The Physical Science Basis. Contribution of Working Group I to the Fifth Assessment Report of the Intergovernmental Panel on Climate Change (eds T.F. Stocker, D. Qin, G.-K. Plattner, M. Tignor, S. K. Allen, J. Boschung et al.), pp. 3-29. Cambridge University Press, Cambridge, UK, and New York, USA.

IUCN (2015) The IUCN Red List of Threatened Species v. 2015.4. Http:// www.iucnredlist.org [accessed 18 December 2015].

Li, Y., Cohen, J.M. \& Rohr, J.R. (2013) Review and synthesis of the effects of climate change on amphibians. Integrative Zoology, 8, 145-161.

Lips, K.R., Diffendorfer, J., Mendelson, III, J.R. \& Sears, M.W. (2008) Riding the wave: reconciling the roles of disease and climate change in amphibian declines. PLoS Biology, 6(3), e72.

Mantyka-Pringle, C.S., Martin, T.G. \& Rhodes, J.R. (2012) Interactions between climate and habitat loss effects on biodiversity: a systematic review and meta-analysis. Global Change Biology, 18, 1239-1252.

Mantyka - Pringle, C.S., Martin, T.G., Moffatt, D.B., Linke, S. \& RHODES, J.R. (2014) Understanding and predicting the combined effects of climate change and land-use change on freshwater macroinvertebrates and fish. Journal of Applied Ecology, 51, 572-581.

Mateo, J. \& Acevedo, M. (1989) Regionalización físico-geográfica. In Nuevo Atlas Nacional de Cuba (eds G. Oliva, E. Lluís \& E.A. Sánchez), p. XII.2.1. Instituto Geográfico Nacional de España, Madrid, Spain.

Moss, R., Babiker, M., Brinkman, S., Calvo, E., Carter, T., Edmonds, J. et al. (2008) Towards New Scenarios for Analysis of Emissions, Climate Change, Impacts, and Response Strategies. Technical summary. Intergovernmental Panel on Climate Change, Geneva, Switzerland.

Nori, J., Lemes, P., Urbina-Cardona, N., Baldo, D., Lescano, J. \& Loyola, R. (2015) Amphibian conservation, land-use changes and protected areas: a global overview. Biological Conservation, 191, 367-374.

Peterson, A.T., Papes, M. \& Eaton, M. (2007) Transferability and model evaluation in ecological niche modeling: a comparison of GARP and Maxent. Ecography, 30, 550-560.

Peterson, A.T., Soberón, J., Pearson, R.G., Anderson, R.P., Martínez-Meyer, E., Nakamura, M. \& Araújo, M.B. (2011) Ecological Niches and Geographic Distributions. Princeton University Press, Princeton, USA.

Phillips, S.J., Anderson, R.P. \& Schapire, R.E. (2006) Maximum entropy modeling of species geographic distributions. Ecological Modelling, 190, 231-259.

Pounds, J.A., Bustamante, M.R., Coloma, L.A., Consuegra, J.A., Fogden, M.P.L., Foster, P.N. et al. (2006) Widespread amphibian extinctions from epidemic disease driven by global warming. Nature, 439, 161-167.

PYKE, C.R. (2004) Habitat loss confounds climate change impacts. Frontiers in Ecology and the Environment, 2, 178-182.

QGIS Development Team (2015) QGIS: A Free and Open Source Geographic Information System. Http://qgis.osgeo.org.

Radosavljevic, A. \& Anderson, R.P. (2014) Making better Maxent models of species distributions: complexity, overfitting and evaluation. Journal of Biogeography, 41, 629-643. 
Raxworthy, C.J., Pearson, R.G., Rabibisoa, N., RakotondraZaFy, A.M., Ramanamanjato, J., Raselimanana, A.P. et al. (2008) Extinction vulnerability of tropical montane endemism from warming and upslope displacement: a preliminary appraisal for the highest massif in Madagascar. Global Change Biology, 14, 1703-1720.

Rödder, D., Kielgast, J. \& Lötters, S. (2010) Future potential distribution of the emerging amphibian chytrid fungus under anthropogenic climate change. Diseases of Aquatic Organisms, 92, 201-207.

Rohr, J.R., Raffel, T.R., Romansic, J.M., McCallum, H. \& Hudson, P.J. (2008) Evaluating the links between climate, disease spread, and amphibian declines. Proceedings of the National Academy of Sciences of the United States of America, 105, 1743617441.

Sodhi, N.S., Bickford, D., Diesmos, A.C., Lee, T.M., Koh, L.P., Brook, B.W. et al. (2008) Measuring the meltdown: drivers of global amphibian extinction and decline. PLoS ONE, 3(2), e1636.

Valdés de la Osa, A. \& Ruiz García, F. (1980) Consideraciones sistemáticas sobre Bufo longinasus (Anura: Bufonidae) y descripción de una nueva subespecie. Poeyana, 206, 1-33.

Walther, G.R., Post, E., Convey, P., Menzel, A., Parmesan, C., Beebee, T.J.C. et al. (2002) Ecological responses to recent climate change. Nature, 416, 389-395.
WARren, D.L. \& Seifert, S.N. (2011) Ecological niche modeling in Maxent: the importance of model complexity and the performance of model selection criteria. Ecological Applications, 21, 335-342.

Weldon, C., Du Preez, L.H., Hyatt, A.D., Muller, R. \& Spears, R. (2004) Origin of the amphibian chytrid fungus. Emerging Infectious Diseases, 10, 2100-2105.

Williams, S.E. \& Hero, J.-M. (1998) Rainforest frogs of the Australian wet tropics: guild classification and the ecological similarity of declining species. Proceedings of the Royal Society $B$, 265, 597-602.

Zank, C., Becker, F.G., Abadie, M., Baldo, D., Maneyro, R. \& Borges-Martins, M. (2014) Climate change and the distribution of Neotropical red-bellied toads (Melanophryniscus, Anura, Amphibia): how to prioritize species and populations? PLoS ONE, 9(4), e94625.

\section{Biographical sketches}

MARLON E. Совоs' research interests are focused on the biogeography, ecology and conservation of tropical fauna, particularly amphibians. Roberto Alonso Bosch's research interests are focused on the natural history, behaviour, evolution and conservation of Caribbean amphibians and reptiles, with special emphasis on the endemic toads of Cuba. 